\title{
METODE KONSERVASI TANAH DENGAN CARA STRIP RUMPUT
}

(GRASS STRIP)

\author{
M. Yusuf* \\ *Penyuluh Kehutanan pada KPH Cenrana/Dinas Kehutanan Provinsi Sulawesi \\ Selatan \\ *E-Mail: sukunbone@gmail.com
}

\begin{abstract}
Soil conservation on dry land is an effort to improve the function of land for production, so that its potential can be optimized as a source of income. Marginal dry land with critical status is characterized by shallow soil solum, slope slope, erosion rate, and very low organic matter content. The decline in soil quality is caused by two main factors namely the first factors are natural factors consisting of climate, topography, slope, vegetation and soil. The second factor is human activity such as mistakes in land management. In an effort to overcome soil degradation in order to obtain an ideal land in agricultural business, the actions that must be taken in a vegetative way. Vegetative methods include planting according to contour like a strip of grass. Vegetative soil conservation methods with grass strips can reduce soil nutrient loss through erosion, resist surface runoff and also produce forages for livestock
\end{abstract}

Keywords: contour, erosion, grass strips, soil conservation, vegetative

\begin{abstract}
ABSTRAK
Konservasi tanah pada lahan kering merupakan upaya meningkatkan fungsi lahan untuk berproduksi, sehingga potensinya dapat dioptimalkan sebagai sumber pendapatan. Lahan kering marginal yang berstatus kritis dicirikan oleh solum tanah yang dangkal, kemiringan lereng, tingkat erosi, kandungan bahan organik sangat rendah. Menurunnya kualitas tanah disebabkan dua faktor utama yakni faktor faktor pertama adalah faktor alamiah yang terdiri dari iklim, topografi, kemiringan lereng, vegetasi dan tanah. Faktor ke dua adalah ulah manusia seperti kesalahan dalam pengelolaan lahan. Dalam upaya mengatasi degradasi tanah untuk memperoleh lahan yang ideal dalam usaha pertanian, maka tindakan yang harus ditempuh dengan cara vegetatif. Cara vegetatif antara lain penanaman menurut kontur seperti strip rumput. Metode koservasi tanah secara vegetatif dengn strip rumput dapat mengurangi kehilangan unsur hara tanah melalui erosi, menahan aliran permukaan dan juga menghasilkan hijauan untuk ternak
\end{abstract}

Kata kunci : erosi, konservasi tanah, kontur, strip rumput, vegetatif

\section{PENDAHULUAN}

Peningkatan jumlah penduduk berdampak pada peningkatkan intensitas pengelolaan lahan baik di dalam kawasan hutan maupun di luar kawasan hutan di 
wilayah daerah aliran sungai (DAS) hulu untuk memenuhi kebutuhan sandang, pangan, papan dan energi ( Sallata, 2015). Sumberdaya alam yang berupa hutan, tanah, dan air mempunyai peranan yang penting dalam kelangsungan hidup manusia sehingga dalam pemanfaatannya perlu dilakukan secara bijaksana. Dalam Undang-Undang No.23 tahun 1997 tentang Pengelolaan Lingkungan Hidup disebutkan bahwa konservasi sumber daya alam adalah pengelolaan sumber daya alam tak terbaharui untuk menjamin pemanfaatannya secara bijaksana dan sumber daya alam yang terbaharui untuk menjamin kesinambungan ketersediaannya dengan tetap memelihara dan meningkatkan kualitas nilainya. Pemanfaatan lahan tersebut harus sesuai dengan kemampuannya dengan cara yang sesuai dengan kaidah konservasi agar tidak terjadi kerusakan tanah.

Banyaknya kesalahan dalam pengelolaan lahan, khususnya lahan kering, akhir-akhir ini telah mengakibatkan timbulnya berbegai masalah serius seperti erosi tanah. Penurunan kualitas lahan karena erosi merupakan awal dari proses degradasi lahan. Lahan kritis dan erosi tanah merupakan salah satu permasalahan yang timbul berkaitan dengan faktor penurunan kualitas lingkungan, sehingga mengakibatkan kesuburan tanah menurun, keseimbangan hidrologi terganggu serta peningkatan frekuensi banjir dan longsor. Kerusakan sumberdaya alam yang terjadi saat ini telah menyebabkan terganggunya keseimbangan lingkungan hidup daerah aliran sungai. Kondisi seperti ini tercermin pada sering terjadinya erosi, banjir dan kekeringan (Asdak, 2004). Untuk mencegah kerusakan tanah yang berkelanjutan, maka perlu dilakukan konservasi. Konservasi tanah adalah penempatan setiap bidang tanah pada cara penggunaan yang sesuai dengan kemampuan tanah tersebut dan memperlakukkannya sesuai dengan syarat-syarat yang diperluka agar tidak terjadi kerusakan tanah (Arsyad, 1989). Pada dasarnya teknik konservasi dibedakan menjadi tiga yaitu: (a) vegetatif; (b) mekanik; dan (c) kimia. Tujuan konservasi tanah adalah meningkatkan produktivitas lahan secara maksimal, memperbaiki lahan yang rusak/kritis, dan melakukan upaya pencegahan kerusakan tanah akibat erosi (Subagyono dkk., 2003).

Metode konservasi vegetatif adalah penggunaan tanaman dan sisa-sisa tanaman untuk mengurangi daya penghancuran tanah oleh butiran hujan yang 
mengurangi jumlah dan daya perusak aliran permukaan (Arsyad 1989). Teknik konservasi tanah secara vegetatif mempunyai beberapa keunggulan dibandingkan dengan teknik konservasi tanah secara mekanis maupun kimia, antara lain karena penerapannya relatif mudah, biaya yang dibutuhkan relatif murah, mampu menyediakan tambahan hara bagi tanaman, menghasilkan hijauan pakan, kayu, buah maupun hasil tanaman lainnya. Hal tersebut melatar belakangi pentingnya informasi mengenai teknologi konservasi tanah secara vegetatif (Subagyono dkk., 2003). Sehubungan dengan hal tersebut di atas maka tulisan ini membahas tentang metode konservasi tanah secara vegetatif menggunakan strip rumput (grass strip)

\section{PERMASALAHAN}

Walaupun dari tahun ke tahun upaya konservasi tanah selalu dilakukan, tetapi belum dapat mencapai hasil yang optimal. Hal ini dibuktikan dengan masih banyaknya kejadian bencana alam banjir dan kekeringan serta menurunnya produktivitas tanah. Kendala penerapan teknologi konservasi tanah secara vegetatif antara lain adalah ketidaktahuan petani terhadap paket teknologi konservasi maupun proses degradasi lahan akibat pengelolaan lahan yang buruk. Petani juga melihat bahwa teknik vegetatif ini akan mengurangi areal produktif bagi tanaman pangan mereka. Petani mempunyai modal yang terbatas, sehingga petani lebih memilih mengelola lahan pertaniannya seefektif mungkin untuk menghasilkan keuntungan yang sebesar-besarnya pada waktu panen. Tindakan konservasi yang baik mendapatkan porsi yang sedikit atau bahkan tidak sama sekali. Kendala-kendala tersebut harus diupayakan untuk dipecahkan bersama sehingga kualitas teknik konservasi yang sudah ada ataupun yang akan diusahakan dapat bertahan bahkan meningkat.

\section{PEMBAHASAN}

\section{a. Metode koservasi secara vegetatif}

Konservasi tanah secara vegetatif merupakan salah satu cara konservasi tanah dengan memanfaatkan tanaman ataupun sisa-sisa tanaman untuk mengurangi erosi. Teknik konservasi tanah secara vegetatif yang akan diuraikan 
dalam monograf ini adalah: penghutanan kembali (reforestation), wanatani (agroforestry) termasuk didalamnya adalah pertanaman lorong (alley cropping), pertanaman menurut strip (strip cropping), strip rumput (grass strip) barisan sisa tanaman, tanaman penutup tanah (cover crop), penerapan pola tanam termasuk di dalamnya adalah pergiliran tanaman (crop rotation), tumpang sari (intercropping), dan tumpang gilir (relay cropping) (Subagyono dkk., 2003)..

\section{b. Strip Rumput (grass strip)}

Penanaman dalam strip didefinisikan sebagai produksi dua atau lebih tanaman dalam bidang yang sama dalam jalur yang cukup luas sehingga masingmasing dapat dikelola secara mandiri oleh mesin yang ada; namun cukup sempit sehingga komponen strip dapat berinteraksi (Hauggaard-Nielsen, 2010). Syarat utam penanaman strip rumput menurut Badan Penelitian dan Pengembangan Pertanian (2007) adalah sebagai berikut :

a. Terutama bagi rumah tangga yang memiliki ternak ruminansia.

b. Cocok untuk daerah beriklim kering maupun daerah beriklim basah.

c. Jenis rumput yang digunakan mempunyai penyebaran perakaran vertikal yang dalam sehingga daya saingnya terhadap tanaman utama menjadi rendah.

d. Jenis rumput yang tahan naungan dan kekeringan.

e. Mempunyai daya adaptasi yang tinggi pada tanah yang tidak subur.

f. Sangat baik jika memberikan efek alelopati terhadap hama.

Menurut Seta (1991) bahwa sistem penanaman dalam strip semua pengolahan tanah harus dilakukan memotong arah lereng. Disamping itu, dalam strip cropping ini juga dianjurkan adanya pergiliran tanaman, bahkan pada tanahtanah yang mudah tererosi (erodibilitasnya tinggi) disarankan agar salah satu tanaman dalam strip merupakan tanaman permanen dalam menutup tanah.

Ada tiga macam metode penanaman dalam strip (Troeh et al., 1980), yakni:

a. penanaman dalam strip menurut garis contur (contour strip croping)

b. penanaman dalam strip lapangan (field strip cropping) dan

c. penanaman dalam strip penyanggah (buffer Strip croping).

Menurut Seta (1991) bahwa pada contour strip cropping, penanaman tanaman dilakukan sejajar dengan garis kontur. Karena itu sistem ini hanya 
dapat diterapkan pada lahan-lahan yang lerengnya panjang dan rata atau seragam (Gambar 1). Pada field strip cropping, penanaman tidak terlalu persis sejajar garis kontur namun cukup dilakukan memotong lereng dengan lebar strip yang seragam (Gambar 2). Sistem ini terutama dilakukan pada lahan-lahan yang mempunyai kelerengan tidak teratur. Pada buffer strip cropping, di antara tanaman pokok ditanaman tanaman penyanggah (pengawet tanah) misalnya leguminosa atau rumput-rumputan yang sifatnya permanen dalam menutup tanah. Sistem ini dilakukan untuk mengatasi lahan-lahan yang sangat ekstrim dengan kelerengan yang tidak terarur (Gambar 3).

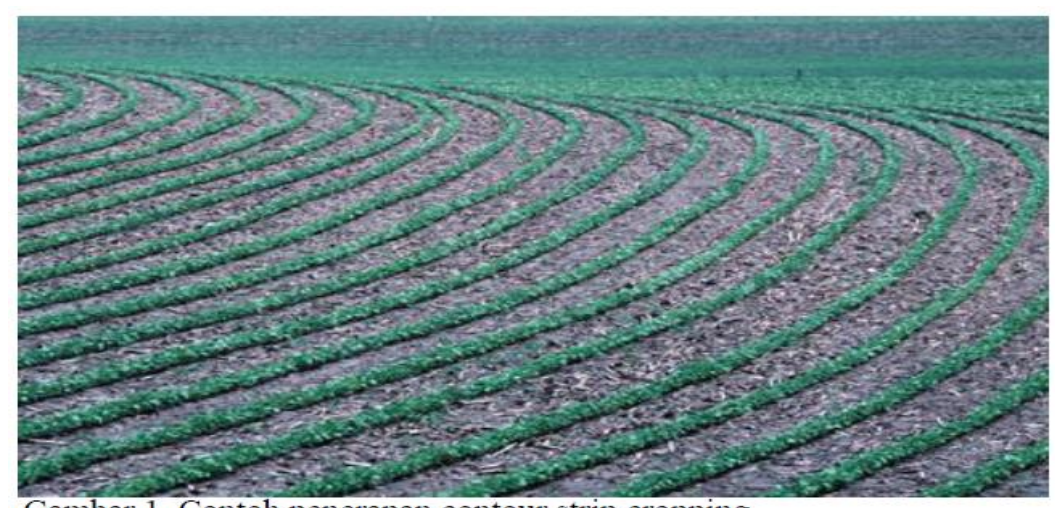

Gambar 1. Contoh penerapan contour strip cropping

Sumber : https://www.google.com/search?q=contour+strip+cropping

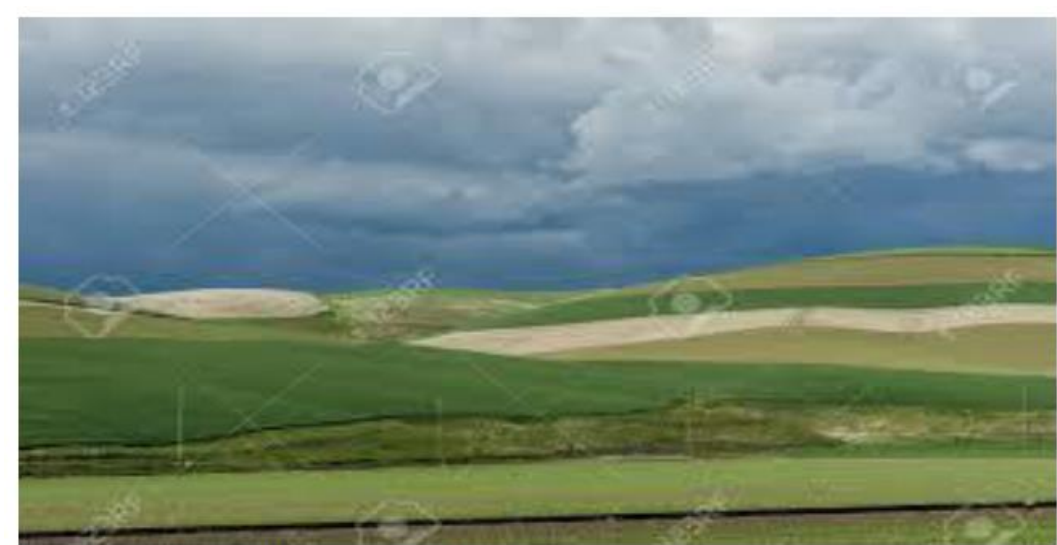

Gambar 2. Contoh penerapan field strip cropping Sumber : https://www.google.com/search?q=field+strip+cropping

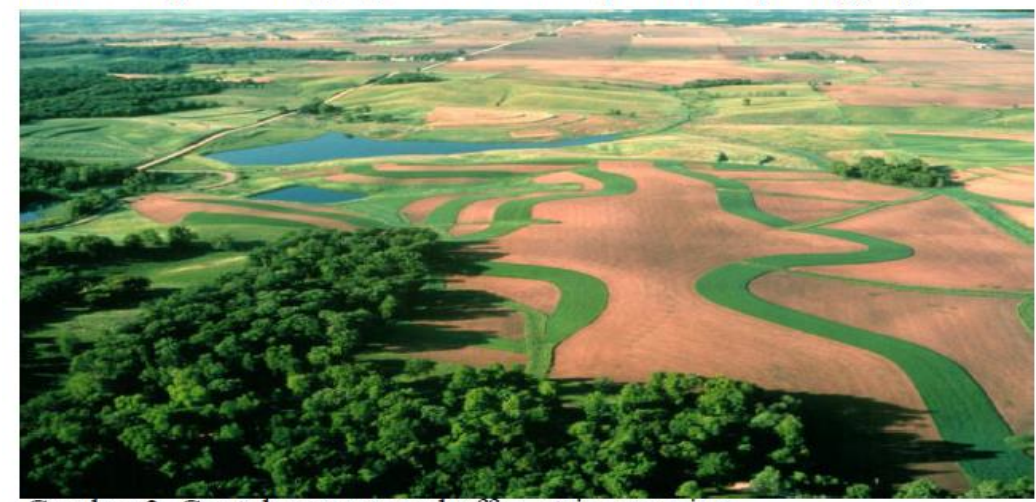

Gambar 3. Contoh penerapan buffer strip cropping

Sumber : https:/www.google.com/search?q=buffer+strip+cropping 


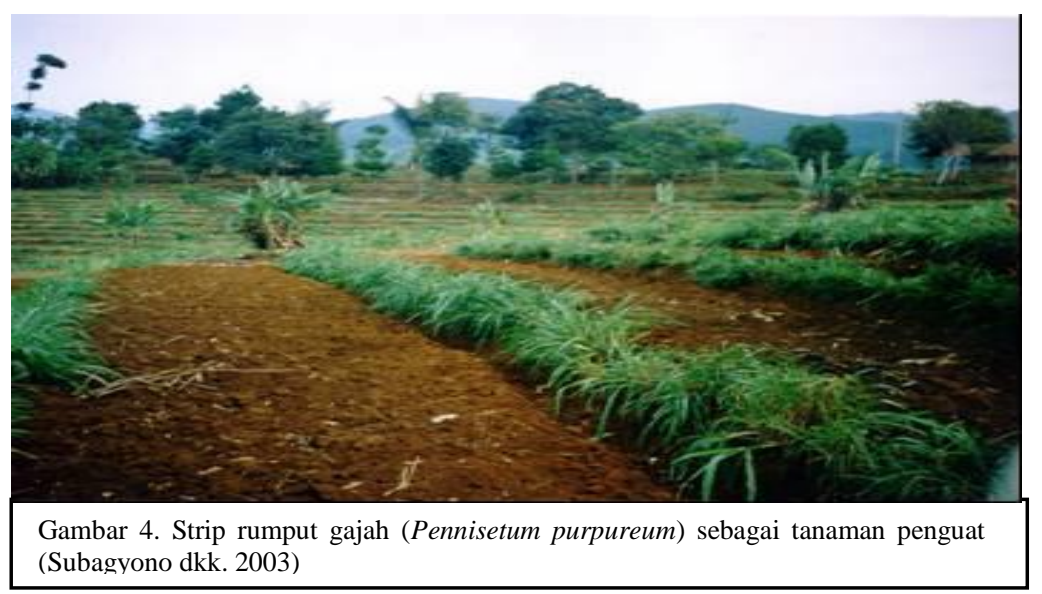

Menurut Morgan (1979) bahwa penanaman dalam strip hanya efektif untuk lahan-lahan yang kelerengannya tidak lebih dari 8,5\%. Teknik konservasi dengan strip rumput (grass strip) biasanya menggunakan rumput yang didatangkan dari luar areal lahan, yang dikelola dan sengaja ditanam secara strip menurut garis kontur untuk mengurangi aliran permukaan dan sebagai sumber pakan ternak . Contoh konservasi tanah secara vegetatif yang menggunakan strip rumput dapat dilihat pada Gambar 4.

Keefektifan dan kemampuan strip rumput (grass strip) untuk menahan kehilangan unsur hara tanah melalui erosi telah dilaporkan oleh beberapa peneliti. Rumput Vetiver yang ditanam sebagai strip minimum 3 baris tanaman mampu mengurangi kehilangan hara melalui erosi (Rehulina, 1991). Untuk lahan dengan lereng di bawah 20\%, metode strip rumput (grass strip) sangat efektif menahan partikel tanah yang tererosi dan menahan aliran permukaan (Suhardjo et al., 1997; Abdurachman dkk., 1982; Abujamin, 1978). Metode strip menggunakan rumput bede (Brachiariadecumbens) sebagai strip selebar 0,5 m dan rumput bahia (Paspalum notatum) sebagai strip selebar $1 \mathrm{~m}$ pada lahan dengan lereng $15-22 \%$, menunjukkan bahwa penggunaan strip rumput dapat menekan tingkat erosi dengan baik. Strip rumput bahia selebar $1 \mathrm{~m}$ mampu menekan erosi sampai mendekati 0 tha pada tahun kedua setelah penanaman. Strip rumput sangat bagus jika dikombinasikan dengan usaha peternakan. Penanaman rumput secara strip dapat diintegrasikan dengan penggemukan sapi(Watung et al., 2003 dan Subagyono et al., 2004). Hasil pangkasan strip 
dapat dimanfaatkan untuk pakan ternak sedangkan kotoran ternak dapat dimanfaatkan sebagai pupuk kandang.

\section{KESIMPULAN}

Berdasarkan pembahasan, maka dapat disimulkan bahwa :

1. Metode koservasi tanah secara vegetatif dapat mengurangi kehilangan unsur hara tanah melalui erosi

2. Metode konservasi dengn strip rumput selain menahan aliran permukaan, juga menghasilkan hijauan untuk ternak

\section{DAFTAR PUSTAKA}

Abdurachman, A., S. Abujamin, dan Suwardjo. 1982. Beberapa cara konservasi tanah pada areal pertanian rakyat. Disampaikan pada Pertemuan Tahunan Perbaikan Rekomendasi Teknologi tgl. 13-15 April. Pusat Penelitian Tanah, Bogor

Abujamin, S. 1978. Peranan rumput dalam usaha konservasi tanah. Seminar LP. Tanah, 8 Juli 1978.

Arsyad, S. 1989. Konservasi Tanah dan Air. Penerbit IPB. Bogor

Asdak, C. 2004. Hidrologi dan Pengelolaan Daerah Aliran Sungai. Penerbit Gadjah Mada University Press, Yogyakarta

Hauggaard-Nielsen, H. 2010. Strip cropping system for sustainable food and energy production. Ris $\varnothing$ National Laboratory for Sustainable Energy Biosystems Division, Technical University of Denmark

Morgan, R.P.C. 1979. Soil Erosion. Longman, London

Rehulina, M. 1991. Pengaruh Strip Rumut Vetiver dan Sistem Pengelolaan Tanah-Sisa Tanaman Terhadap Konsentrasi dan Kehilangan C-Organik, $\mathrm{N}$ dan $\mathrm{P}$ Melalui Erosi pada Dystropept Oksik (Latosol Coklat Kemerahan) Darmaga. Skripsi. Jurusan Ilmu Tanah, Fakultas Pertanian, IPB, Bogor.

Sallata, M.K. 2015. Konservasi dan Pengelolaan Sumber Daya Air Berdasarkan Keberadaannya Sebagai Sumber Daya Alam. Info Teknis EBONI. 12 (1) : $75-86$

Seta, A. K. 1991. Konservasi Sumberdaya Tanah dan Air. Cetakan kedua. Kalam Mulia, Jakarta. 
Subagyono, K., S. Marwanto dan U. Kurnia.2003. Teknik Konservasi Tanah Secara Vegetatif. Balai Penelitian Tanah dan Agroklimat. Badan enelitian dan Pengembangan Pertanian, Deppartemen Pertanian.

Subagyono, K., T. Vadari, Sukristiyonubowo, R.L. Watung, and F. Agus.2004. Land Management for Controlling Soil Erosion at Micro catchment Scale in Indonesia. p. 39-81. In Maglinao, A.R. and C. Valentin (Eds.) Community-Based Land and Water Management Systems for Sustainable Upland Development in Asia: MSEC Phase 2. 2003 Annual Report. International Water management Institute (IWMI). Southeast Asia Regional Office. Bangkok. Thailand

Suhardjo, M., A. Abas Idjudin, dan Maswar. 1997. Evaluasi beberapa macam strip rumput dalam usaha pengendalian erosi pada lahan kering berteras di lereng perbukitan kritis D.I. Yogyakarta. hlm. 143-150 dalam Prosiding Seminar Rekayasa Teknologi Sistem Usahatani Konservasi. Bagian Proyek Penelitian Terapan Sistem DAS Kawasan Perbukitan Kritis Yogyakarta (YUADP Komponen-8).Badan Penelitian dan Pengembangan Pertanian.

Troeh, F.R., J.A. Hobbs, and R. L. Donahue. 1980. Soil and Water Conservation for : Productivity and Environmental Protection. Prentice-Hall Inc., Englewood Cliffts.

Undang-Undang Republik Indonesia Nomor 23 tahun 1997, tentang pengelolaan lingkungan hidup

Watung, R.L., T. Vadari, Sukristiyonubowo, Subiharta, and F. Agus. 2003. Managing Soil Erosion in Kaligarang Catchment of Java, Indonesia. Phase 1 Project Completion Report. International Water management Institute (IWMI). Southeast Asia Regional Office. Bangkok. Thailand 